\title{
EXAMINING THE EFFECTS OF HAND ANTHROPOMETRIC MEASUREMENTS, GRIP STRENGTH AND BALANCE SKILLS ON SHOT PERFORMANCE IN ELITE FEMALE BASKETBALL PLAYERS
}

\author{
Serdar Gürii, \\ Mehmet Soyal ${ }^{2}$ \\ ${ }^{1}$ Istanbul Gelisim University, \\ Vocational School, \\ Turkey \\ ${ }^{2}$ Istanbul Gelisim University, \\ School of Physical Education and Sports, \\ Turkey
}

\begin{abstract}
:
This study aims to examine the effects of elite female basketball players' hand anthropometric measurements, hand-grip strength and balance skills on their shooting performance. The age, height, weight, body mass index and hand anthropometric values, hand-grip strength and balance of the athletes were measured, and Aahperd shot tests were applied. Data analysis was performed through SPSS 24 package program. Data analyses included the Shapiro-Wilk Test applied to determine whether there is a normal distribution, and Pearson correlation analysis used to evaluate the correlation status of the parameters with the normal distribution of the data. The average age of the 12 female athletes participating in the study was $21.83 \pm 4.407$ years, the average height was 171.50 $\pm 6.95 \mathrm{~cm}$, the average body weight was $68.60 \pm 17.96 \mathrm{~kg}$ and the mean Body Mass Index was $23.99 \pm 4.72$. has been determined. It was determined that the average right hand grip strength of 12 female athletes participating in the study was $35.92 \pm 6.127 \mathrm{~kg}$ and the average left hand grip strength was $32.92 \pm 5.807 \mathrm{~kg}$. Among the balance parameters, the balance mean deviation value was determined as $07 \pm, 048$, the balance average speed value as $42 \pm 119$, the balance path length value as $12.19 \pm 3.473$ and the balance area value as $02 \pm$. The Aahperd shot test mean value was also determined to be $18.67 \pm 2.425$. The analyses regarding the hand anthropometrics parameter of the 12 athletes indicate that there is no significant correlation between shot performance and hand length, width, palm length, third finger length, hand shape index, finger index and hand surface area. Besides, it is determined that there is no significant correlation between the hand grip strength and balance test results and shooting performance. The data revealed that the
\end{abstract}

${ }^{i}$ Correspondence: email segur@gelisim.edu.tr 
dominant hand measurements, test values and shooting performance of the athletes are not significantly correlated.

Keywords: evaluation, training, stability, gripping force, shooting precision

\section{Introduction}

Considering the offensive and defensive actions in basketball, it is observed that it includes technical actions such as dribbling, passing, shooting, rebound, sprinting, changing direction and defensive slipping that players try to implement successfully (Krause and Nelson, 2018). It is widely stated that one of the most important technical actions in basketball is the shooting skill (Erculj and Supej, 2009; Okazaki et al. 2007). Although shooting is the most difficult and complex skill to develop among the physical skills utilized in a basketball match, it is one of the most important factors determining the score superiority in a game and the winning side (Malone et al. 2002). It is known that as a result of the developments in training science, the quality of different training methods has increased and thus reflected on physical performance. During the competition, it is possible to mention that the accuracy of the shooting percentage may increase with the extra shooting training of the athletes with advanced motoric features (Savas et al. 2018).

Considering these and similar statements in the literature about shooting skill in basketball, we can say that there are many parameters that are likely to affect the athlete's shooting performance during the match. One of the parameters we examine in this study is the anthropometric measurement and values of the hand. In basketball, athletes' long hand fingers can positively affect shooting performance, and athletes with long fingers and a large hand surface are likely to have more hand grip strength (Visnapuu and Jurimae, 2007).

One of these parameters is hand grip strength, since the wrist and finger flexors constantly display manipulative skills, such as holding, catching, shooting in basketball, which is a game played by hand (Visnapuu and Jurimae, 2007; Cortis et al. 2011).

Hand grip strength is a measure of hand grip strength governed by many muscle groups in the hand and forearm. The muscles in this region, while enabling daily activities such as holding or manipulating objects in different situations, play an important role in performing the necessary manipulation for basketball to throw the ball in the desired direction at the right angle (Bassey and Harries, 1993).

Another parameter that is likely to affect shooting performance that we examined in this study is balance skill. Balance feature is one of the most important coordination skills for basketball (Kostopoulos et al. 2012). In basketball, it is very necessary to maintain balance and maintain this balance in technical actions such as dibling, passing, shooting, etc Kaushik and Sharma, 2013).

When the literature is examined, it is seen that there are few studies that examine the three parameters that are likely to affect the shot performance discussed in this study. 
Due to the scarcity of resources in the literature, the aim of this study is to examine the effects of seven different anthropometric measurements of the hand, hand grip strength and static balance skill on shooting performance in elite female basketball players.

\section{Material and Methods}

\subsection{Research Model}

The correlational survey model of the quantitative tradition was applied. The correlational survey model is a survey model that aims to determine the covariance between two or more variables and its degree (Karasar, 2011).

\subsection{Research Group}

The study sample comprises 12 female athletes licensed to the Çeşme Basketball Sports Club (A team) competing in the TBF Women $1^{\text {st }}$ League.

The study was conducted in a manner that respected the principles established by the Declaration of Helsinki and it was approved by the Ethics Committee of the University.

\subsection{Data Collection Tools}

12 elite female basketball players aged 17 and over at Çeşme Basketball Sports Club voluntarily participated in the study. A written consent form was obtained from the club administration, and the measurements were performed within this framework. All the information about the measurements was provided to the athletes, and all athletes had the choice to try the measurements beforehand to provide equal skill right. An electronic digital caliper with $150 \mathrm{~mm}, 0.01 \mathrm{~mm} / 0.0005$-inch precision was used for hand anthropometric measurements, a hand dynamometer to measure hand grip strength, and the Sigma Balance Platform to measure balance. The Aahperd shooting test was applied to determine the participants' shooting performance. First, age, height and body weight were documented for the entire athlete group.

\section{a. Height Measurements}

The height of the athletes was measured with a tape measure fixed on the wall with the zero indicator touching the ground. The measurements were performed with athletes on bare feet. The values obtained were recorded in "cm" (Lohman et al. 1988).

\section{b. Weight Measurements}

Athlete weights were measured using a digital scale. The athletes participated in the measurement only with shorts and t-shirts. The values obtained were recorded in "kg" (Lohman et al. 1988). 


\section{c. Body Mass Index Measurements}

The height and weight data were used to calculate the "Body Mass Index", which explains the weight distribution according to the height (Lohman et al. 1988). Body Mass Index $(\mathrm{BMI})=$ Weight $/$ Height $\left(\mathrm{m}^{2}\right)$.

\section{d. Hand Anthropometric Measurements}

The hand anthropometric measurements were performed with a "Shan" brand (150 mm) electronic digital caliper with $0.01 \mathrm{~mm} / 0.0005$ inch precision. The hand length, width, palm length and third finger lengths were measured distinctly for right and left hand. The measurement was performed from the palmar side with the $2^{\text {nd }}-5^{\text {th }}$ fingers in adduction and the thumb in some extension, maintaining a position with the fingers stretched in contact with a flat and hard surface (Kulaksiz, 2001). Moreover, the formulas below were used to obtain the shape index, finger index and hand surface area values from the data.

The hand length measurement was performed while the midpoint on the distal line (plica carpalis distalis) that forms the boundary between the hand and the wrist was taken as the basis, and the distance to the tip of the middle finger was recorded (Kulaksiz, 2001; Hall et al. 1999; Pheasant, 1990).

The hand width measurement was conducted through the distance formed between the proximal ends of the $2^{\text {nd }}$ and $5^{\text {th }}$ metacarpophalangeal joints (Kulaksiz, 2001; Hall et al. 1999; Pheasant, 1990).

The palm length measurement through recording the distance between the midpoint of the proximal line (plica digitopalmaris) that separates the root of the middle finger from the palm and the midpoint of the distal line (plica carpalis distalis) that forms the boundary between the hand wrist (Kulaksız, 2001; Hall et al. 1999; Pheasant, 1990).

The third finger length was measured from the middle point on the proximal line (plica digitopalmaris) that separates the root of the finger from the palm of the middle finger as the basis, and the distance to the tip of the middle finger was recorded (Kulaksiz, 2001; Hall et al. 1999; Pheasant, 1990).

The shape index was calculated through the formula as (hand width $x 100$ ) / hand length. High unit values in this index, which enables the hand shape evaluation, indicate that the person has a large hand structure, and the low unit values indicate that the person has a delicate hand structure (Kulaksiz, 2001; Napier, 1990).

The finger index is measured with the formula as ( $3^{\text {rd }}$ finger length $\left.x 100\right) /$ hand length. The ratio of the third finder length to the hand length was considered as the finger index. Higher values of finger index show that the finger length is longer compared to the hand length. Moreover, it provides the information that these people have more grip ability. Low finger index values indicate strong hands (Kulaksız, 2001).

It is a measurement obtained by multiplying the hand length and hand width of athletes in inch ${ }^{2}$. This value is also important regarding its relation to the hand grip strength. Hand Surface Area $\left(\right.$ inch $\left.^{2}\right)=$ Hand Length (inch) $\times$ Hand Width (inch) (Agarwal and Sahu, 2010). 


\section{e. Hand Grip Strength Measurement}

"Saehan" brand hydraulic hand dynamometer was used to measure the grip strength. The test was performed by measuring the grip strength for both hands during the grip strength measurement with this tool. Measurements were recorded in the elbow flexion position with two trials for both right and left hands. The higher value of these two measurements was recorded in $\mathrm{kg}$. The dynamometer was calibrated and adjusted according to the athletes' hand while measuring grip strength (Tamer, 2000; Kamar, 2003).

\section{f. Balance Test}

A double leg static balance test was performed using the computer-aided stabilometer device Sigma Digital Balance Platform. Special attention was paid to the air condition of the measurement environment, and it was sufficiently quiet during the balance measurements. The athletes started the test on the Sigma Digital Balance Platform with bare feet, and they were asked to balance on the platform for 30 seconds without touching the ground. The measurement was repeated twice, and the best result was recorded (Zemková, 2011).

\section{g. Aahperd Shot Test}

The Aahperd shooting test aims to measure the shooting skills of the athletes. The zones where the shooting will take place are measured 4.57 meters away from the projection of the hoop, through 5 equally distanced training plates placed from the projection of the center of the hoop and marked on the ground. The subjects were asked to shoot from the first point to the hoop and shoot again from the other points after taking the ball and dribbling to the next point within 1 minute. It was ensured that at least one shot was thrown from each of the 5 shooting points and that at least one foot was behind the marked shooting areas. The test subjects were allowed to attempt a lay-up with the ball they received after missed shots on the conditions that they do not take consecutive layups and that do not try them more than 4 times. Subjects continued to shoot or took layups from the 5 shooting points until a stop warning was blown. The shooting test was ended when the one minute time has elapsed. Each successful shot is scored as 2 points, and missed shots were counted as 1 . If the lay-up is successful with a ball returning from the hoop, it is scored as 2 points. If two successful lay-ups are made in a row, the second one is not scored. No points were awarded for shots made with violations in dribbling, ball handling and the shooting line (Mülazımoğlu, 2012).

\subsection{Statistical Analysis}

The data regarding each athlete recorded in the subject evaluation form was analyzed through the SPSS 24 package program.

Descriptive statistics were used to determine the data averages, and the results obtained were presented as average $(X) \pm$ standard deviation (SD). The Shapiro-Wilk test was applied to determine whether the data show a normal distribution, and the skewness 
and kurtosis coefficients were found to be in the range of \pm 3 . Kalaycl et al., argued that coefficient values in the range of \pm 3 might be considered as acceptable (Büyüköztürk, 2007). Pearson's correlation analysis was applied to assess the correlation status of the parameters with a normal distribution of the data. The variable averages and standard deviations of all athletes were calculated, and values below $p<0.05$ were considered statistically significant.

\section{Results}

Table 1: Demographic Features of the Participants

\begin{tabular}{|l|c|c|c|c|}
\hline Variables & $\mathbf{n}$ & $\mathbf{X} \pm$ SD & Minimum & Maximum \\
\hline Age $($ year $)$ & 12 & $21,83 \pm 4,407$ & 17 & 35 \\
\hline Height $(\mathrm{cm})$ & 12 & $171,50 \pm 6,95$ & 163 & 182 \\
\hline Weight $(\mathrm{kg})$ & 12 & $68,60 \pm 17,96$ & 51 & 115 \\
\hline BMI $\left(\mathrm{kg} / \mathrm{m}^{2}\right)$ & 12 & $23,99 \pm 4,72$ & 18,98 & 35,43 \\
\hline
\end{tabular}

Table 1 shows that the average age of 12 female athletes was 21.83 \pm 4.407 , average height was $171.50 \pm 6.95 \mathrm{~cm}$, while mean body weight was $68.60 \pm 17.96 \mathrm{~kg}$ and mean Body Mass Index was $23.99 \pm 4.72$.

Table 2: Right Hand Anthropometric Measurements

\begin{tabular}{|l|c|c|c|c|}
\hline Variables & $\mathbf{n}$ & $\mathbf{X} \pm \mathbf{S D}$ & Minimum & Maximum \\
\hline Right Hand Length $(\mathrm{cm})$ & 12 & $18,50 \pm 1,352$ & 17 & 21 \\
\hline Right Hand Width $(\mathrm{cm})$ & 12 & $7,43 \pm, 634$ & 7 & 9 \\
\hline Right Hand Palm Length $(\mathrm{cm})$ & 12 & $10,74 \pm, 686$ & 10 & 12 \\
\hline Right Hand Third Finger Length $(\mathrm{cm})$ & 12 & $7,78 \pm, 735$ & 7 & 9 \\
\hline Right Hand Finger Index & 12 & $42,20 \pm 1,501$ & 40 & 45 \\
\hline Right Hand Shape Index & 12 & $40,108 \pm 2,126$ & 37,37 & 44,5 \\
\hline Right Hand Surface Area & 12 & $138,17 \pm 20,899$ & 115,60 & 178 \\
\hline
\end{tabular}

Table 2 shows that the average right hand length of the 12 female athletes was $18.50 \pm 1.352$ $\mathrm{cm}$, width mean $7.43 \pm .634 \mathrm{~cm}$, the average palm length was $10.74 \pm, 686 \mathrm{~cm}$, and the mean third finger length was $7.78 \pm .735 \mathrm{~cm}$. Furthermore, the other anthropometric parameters of the hand were determined as the average right hand finger index was $42.2025 \pm 1.50192$, the mean shape index was $40.10800 \pm 2.12623$, and the average hand surface area was $138.1792 \pm 20.89926$.

Table 3: Left Hand Anthropometric Measurements

\begin{tabular}{|l|c|c|c|c|}
\hline Variables & $\mathbf{n}$ & $\mathbf{X} \pm \mathbf{S D}$ & Minimum & Maximum \\
\hline Left Hand Length $(\mathrm{cm})$ & 12 & $18,45 \pm 1,343$ & 17 & 21 \\
\hline Left Hand Width $(\mathrm{cm})$ & 12 & $7,33 \pm, 566$ & 7 & 9 \\
\hline Left Hand Palm Length $(\mathrm{cm})$ & 12 & $10,73 \pm, 680$ & 10 & 12 \\
\hline Left Hand Third Finger Length $(\mathrm{cm})$ & 12 & $7,81 \pm, 665$ & 7 & 9 \\
\hline Left Hand Finger Index & 12 & $42,30 \pm 1,310$ & 40 & 45 \\
\hline Left Hand Shape Index & 12 & $39,78 \pm 1,918$ & 37,64 & 43 \\
\hline Left Hand Surface Area & 12 & $135,84 \pm 19,664$ & 115,60 & 172 \\
\hline
\end{tabular}


Table 3 presents that the average left hand length of 12 female athletes was $18.45 \pm 1.343$ $\mathrm{cm}$, the mean left hand width was measured as $7.33 \pm, 566 \mathrm{~cm}$, the average palm length was $10.73 \pm, 680 \mathrm{~cm}$, and the average third finger length was $7.81 \pm, 665 \mathrm{~cm}$. Moreover, the other anthropometric parameters of the hand were determined as the mean left hand finger index was $42.3025 \pm 1.31052$, the average shape index was $39.7800 \pm 1.91869$, and the average hand surface area was $135.8492 \pm 19.66429$.

Table 4: Right-Left Hand Grip Strength,

Balance Parameters and Aahperd Shot Test Values

\begin{tabular}{|l|c|c|c|c|}
\hline Variables & $\mathbf{n}$ & $\mathbf{X} \pm$ SD & Minimum & Maximum \\
\hline Right Hand Grip Strength $(\mathrm{kg})$ & 12 & $35,92 \pm 6,127$ & 24 & 44 \\
\hline Left Hand Grip Strength $(\mathrm{kg})$ & 12 & $32,92 \pm 5,807$ & 24 & 42 \\
\hline Balance Standard Deviation & 12 &, $07 \pm, 048$ & 0 & 0 \\
\hline Balance Average Speed & 12 &, $42 \pm, 119$ & 0 & 1 \\
\hline Balance Path Length & 12 & $12,19 \pm 3,473$ & 6 & 17 \\
\hline Balance Area & 12 &, $02 \pm, 009$ & 0 & 0 \\
\hline Aahperd Shot Test (score) & 12 & $18,67 \pm 2,425$ & 15 & 22 \\
\hline
\end{tabular}

Table 4 illustrates that the average right hand grip strength of 12 female athletes was $35.92 \pm 6.127 \mathrm{~kg}$, left hand grip strength mean was measured as $32.92 \pm 5.807 \mathrm{~kg}$. The balance parameters were calculated as the balance standard deviation value was $07 \pm, 048$, the balance average speed value as $42 \pm 119$, the balance path length value as $12.19 \pm 3.473$, and the balance area value as $02 \pm .009$. The Aahperd shot test mean score was calculated as $18.67 \pm 2.425$.

Table 5: The Correlation between Right Hand Anthropometric Measurements and Aahperd Shot Test Results

\begin{tabular}{|l|c|c|c|c|c|c|}
\hline Variables & & $\mathbf{1}$ & $\mathbf{2}$ & $\mathbf{3}$ & $\mathbf{4}$ & $\mathbf{5}$ \\
\hline \multirow{2}{*}{ Right Hand Length } & $\mathrm{r}$ & $\mathbf{1}$ & & & & \\
\hline & $\mathrm{p}$ & - & & & & \\
\hline \multirow{2}{*}{ Right Hand Width } & $\mathrm{r}$ &, 769 & 1 & & & \\
\hline \multirow{2}{*}{ Right Hand Palm Length (cm) } & $\mathrm{p}$ &, $003^{*}$ & - & & & \\
\hline \multirow{2}{*}{ Right Hand Third Finger Length (cm) } & $\mathrm{r}$ &, 963 &, 699 & 1 & & \\
\hline & $\mathrm{p}$ &, $000^{* *}$ &, 011 & - & & \\
\hline \multirow{2}{*}{ Aahperd Shot Test } & $\mathrm{r}$ &, 915 &, 768 &, 798 & 1 & \\
\hline & $\mathrm{p}$ &, 000 &, $004^{*}$ &, $002^{*}$ & - & \\
\hline & $\mathrm{p}$ &,- 180 &,- 181 &,- 286 &,- 177 & 1 \\
\hline
\end{tabular}

${ }^{*} \mathrm{p}<0,05^{* *} \mathrm{p}<0,001$

Table 5 reveals no significant correlation between the Aahperd shot test results and the right hand anthropometric parameters of length, width, palm length, third finger length measurements of the 12 female athletes $(p>0,05)$. 
Table 6: The Correlation between Left Hand

Anthropometric Measurements and Aahperd Shot Test Results

\begin{tabular}{|l|c|c|c|c|c|c|}
\hline Variables & & $\mathbf{1}$ & $\mathbf{2}$ & $\mathbf{3}$ & $\mathbf{4}$ & $\mathbf{5}$ \\
\hline \multirow{2}{*}{ LHL } & $\mathrm{r}$ & $\mathbf{1}$ & & & & \\
\hline & $\mathrm{p}$ & - & & & & \\
\hline \multirow{2}{*}{ Left Hand Width } & $\mathrm{r}$ &, 788 & 1 & & & \\
\hline \multirow{2}{*}{ Left Hand Palm Length (cm) } & $\mathrm{p}$ &, $002^{*}$ & - & & & \\
& $\mathrm{r}$ &, 910 &, 664 & 1 & & \\
\hline \multirow{2}{*}{ Left Hand Third Finger Length (cm) } & $\mathrm{p}$ &, $000^{* *}$ &, 019 & - & & \\
\hline \multirow{2}{*}{ Aaahperd Shot Test } & $\mathrm{r}$ &, 935 &, 832 &, 749 & 1 & \\
\hline & $\mathrm{p}$ &, $000^{* *}$ &, $001^{*}$ &, 005 & - & \\
\hline & $\mathrm{r}$ &,- 201 &,- 044 &,- 171 &,- 178 & 1 \\
\hline & $\mathrm{p}$ &, 531 &, 892 &, 595 &, 579 & - \\
\hline
\end{tabular}

${ }^{*} \mathrm{p}<0,05{ }^{* *} \mathrm{p}<0,001$

Table 6 showed no significant correlation between the Aahperd shot test results and the left hand anthropometric parameters of length, width, palm length and third right finger length measurements of the 12 female athletes $(p>0,05)$.

Table 7: The Correlation between Athletes' Right Hand Finger Index, Shape Index, Surface Area and Aahperd Shot Test Results

\begin{tabular}{|l|c|c|c|c|c|}
\hline Variables & & $\mathbf{1}$ & $\mathbf{2}$ & $\mathbf{3}$ & $\mathbf{4}$ \\
\hline \multirow{2}{*}{ Right Hand Finger Index } & $\mathrm{r}$ & 1 & & & \\
\hline \multirow{2}{*}{ Right Hand Shape Index } & $\mathrm{p}$ & - & & & \\
\hline \multirow{2}{*}{ Right Hand Surface Area } & $\mathrm{r}$ &, 156 & 1 & & \\
\cline { 2 - 6 } & $\mathrm{p}$ &, 629 & - & & \\
\hline \multirow{2}{*}{ Aaahperd Shot Test } & $\mathrm{r}$ &, 292 &, 237 & 1 & \\
\cline { 2 - 6 } & $\mathrm{p}$ &, 358 &, 458 & - & \\
\hline & $\mathrm{r}$ &,- 107 &,- 040 &,- 179 & 1 \\
\hline
\end{tabular}

${ }^{*} \mathrm{p}<0,05^{* *} \mathrm{p}<0,001$

Table 7 illustrated no significant correlation between the Aahperd shot test results and the right hand anthropometric parameters of finger index, shape index and surface area values of the 12 female athletes $(p>0,05)$.

Table 8: The Correlation between Athletes' Left Hand Finger Index, Shape Index, Surface Area and Aahperd Shot Test Results

\begin{tabular}{|l|c|c|c|c|c|}
\hline Variables & & $\mathbf{1}$ & $\mathbf{2}$ & $\mathbf{3}$ & $\mathbf{4}$ \\
\hline \multirow{2}{*}{ Left Hand Finger Index } & $\mathrm{r}$ & 1 & & & \\
\hline \multirow{2}{*}{ Left Hand Shape Index } & $\mathrm{p}$ & - & & & \\
\hline \multirow{2}{*}{ Left Hand Surface Area } & $\mathrm{r}$ &, 295 & 1 & & \\
\cline { 2 - 6 } & $\mathrm{p}$ &, 351 & - & & \\
\hline \multirow{2}{*}{ Aaahperd Shot Test } & $\mathrm{r}$ &,- 116 &, 093 & 1 & \\
\cline { 2 - 6 } & $\mathrm{p}$ &, 718 &, 775 & - & \\
\hline
\end{tabular}

${ }^{*} \mathrm{p}<0.05^{* *} \mathrm{p}<0.001$ 
Table 8 shows no significant correlation between the Aahperd shot test results and the left hand anthropometric parameters of finger index, shape index and surface area values of the 12 female athletes $(p>0,05)$.

Table 9: The Correlation between Balance Parameters, Right-Left Hand Grip Strengths and Aahperd Shot Test Results

\begin{tabular}{|c|c|c|c|c|c|c|c|c|}
\hline Variables & & 1 & 2 & 3 & 4 & 5 & 6 & 7 \\
\hline \multirow{2}{*}{ Balance Standard Deviation } & $\mathrm{r}$ & 1 & & & & & & \\
\hline & $\mathrm{p}$ & - & & & & & & \\
\hline \multirow{2}{*}{ Balance Average Speed } & $\mathrm{r}$ & ,486 & 1 & & & & & \\
\hline & $\mathrm{p}$ & 109 & - & & & & & \\
\hline \multirow{2}{*}{ Balance Path Length } & $\mathrm{r}$ & 493 & ,999 & 1 & & & & \\
\hline & $\mathrm{p}$ & 104 &, $000^{* *}$ & - & & & & \\
\hline \multirow{2}{*}{ Balance Area } & $\mathrm{r}$ & ,632 & ,667 & ,651 & 1 & & & \\
\hline & $\mathrm{p}$ & ,027 & ,018 & ,022 & - & & & \\
\hline \multirow{2}{*}{ Right Hand Grip Strength (kg) } & $\mathrm{r}$ & ,099 &,- 414 &,- 387 &,- 265 & 1 & & \\
\hline & $\mathrm{p}$ & ,759 & ,181 & ,214 &, 405 & - & & \\
\hline \multirow{2}{*}{ Left Hand Grip Strength (kg) } & $\mathrm{r}$ & ,348 &,- 349 &,- 339 &,- 106 & ,779 & 1 & \\
\hline & $\mathrm{p}$ & 268 &, 266 & ,280 & ,744 &, $003^{*}$ & - & \\
\hline \multirow{2}{*}{ Aaahperd Shot Test } & $\mathrm{r}$ &,- 084 &,- 102 &,- 123 & 194 &,- 363 &,- 041 & 1 \\
\hline & $\mathrm{p}$ & 795 & ,753 & ,704 &, 545 & ,246 & 900 & - \\
\hline
\end{tabular}

${ }^{*} \mathrm{p}<0,05{ }^{* *} \mathrm{p}<0,001$

Table 9 revealed no significant relationship between the Aahperd shot test results and balance parameters, right-left hand grip strength values of 12 female athletes $(p>0,05)$.

\section{Discussion}

This section presents the test results of previous studies in the same direction within a comparative tradition.

The average age of 12 elite female athletes in this study was $21.83 \pm 4.407$, as the average height was $171.50 \pm 6.95 \mathrm{~cm}$, mean body weight was $68.60 \pm 17.96 \mathrm{~kg}$ and mean Body Mass Index was 23.99 \pm 4.72 .

Acar (2016), conducted a study on the effects of flexibility in basketball on motor properties in 20 athletes competing in the $2^{\text {nd }}$ League and determined an average age of the athletes as $19.00 \pm 3.83$, mean height as $170.20 \pm 9.31 \mathrm{~cm}$, and body mass index as 20.86 \pm 2.67 . Pazarözyurt and İnce (2009), examined the anthropometric features of vertical jump and spine flexibility in 41 elite female basketball players by playing positions and found that the mean age was $24.21 \pm 5.48$ and the average height was $179 \pm 0.08 \mathrm{~cm}$. Şen, Durgun and Kozanoğlu (2007), evaluated the upper extremity morphological characteristics of 40 athletes (15 male, 25 female) playing basketball in a league with away games by playing positions. The average age of female athletes was $19.0 \pm 2.07$, with an average height of $172.0 \pm 0.51 \mathrm{~cm}$, and a bodyweight of $62.7 \pm 6.85 \mathrm{~kg}$. This study's sample comprised 12 female athletes competing in Turkey Women's Basketball $1^{\text {st }}$ League, and it 
can be asserted that the average age, body weight, height and body mass index values are similar to the previous results reached by contemporary studies.

This study found no statistically significant correlation between the hand anthropometric parameters of right hand length, width, palm length, third finger length, shape index, finger index, surface area values and Aahperd shot test results $(p>0.05)$.

Furthermore, it was discovered that there is no statistically significant correlation between the hand anthropometric parameters of left hand length, width, palm length, third finger length, shape index, finger index, surface area values, and Aahperd shot test results $(\mathrm{p}>0.05)$.

Teramoto, Cross, Rieger, Maak, and Willick (2018), used the NBA Draft Combine measurements to examine the correlation between hand length and 2-point shot percentage in their study on the correlation between anthropometric properties and shooting performance. It was found that there was a significant correlation between hand length and two-point shooting performance and no significant correlation between hand length and 3-point shot percentage. Barut, Demirel, and Kiran (2008), used hand length measurements and 2-point field goals made in their study and revealed a weak correlation between hand length and the percentage of 2-point shot accuracy. Barut et al. (2008), sampled 145 basketball, 96 handball players and 133 volleyball players aged between 9 and 18. The measurements applied to basketball athletes revealed no correlation between the hand measurements and the 2-point shot percentage. $\mathrm{Ziv}$ and Lidor (2009), conducted tests on performance indicators of statistical parameters related to competitions besides the physical and anthropometric parameters and found no statistically significant correlation between hand length and shooting performance. Teramoto et al. (2018), compared the anthropometric properties and shooting performance using the NBA Draft Combine measurements, and there was no significant correlation between the hand difference measurements and the 2-point shot percentage. Şen et al. (2007), examined the correlation between hand width measurements and 2 point shot percentage and found a statistically weak correlation between them. Teramoto et al. (2018), used the NBA Draft Combine measurements for a study on anthropometric properties and shot performance and found a weak correlation between hand width and 2-point shot percentage as it was stated that there was no significant correlation between hand width and 3-point shot percentage. Barut et al. (2008), revealed a weak correlation between hand width and 2-point shot percentage as there was no significant correlation between hand width and 3-point shot percentage. The contemporary scholarship hints at results indicated correlations between hand anthropometric measurements and shooting performance which confirms the study results.

Kulaksiz (2001), found the mean right hand shape index as $45.2934 \pm 2.0408$ and an average left hand shape index as $44.6750 \pm 2.0730$ in the study on hand anthropometric measurements. Demirel (2005), conducted a study on hand anthropometric measurements and examined three different age categories in the basketball branch. The mean right finger index in the junior category was $42.66 \pm 1.26$, as the right finger index in the stars category was $43.51 \pm 1.66$, and the right finger index in the youth category was 
43.39 \pm 1.20 . Attila (2019) studied the correlation between hand anthropometric measurements and shooting performances in elite basketball players. The author detected a weak correlation between the hand surface area and the 2-point shot percentage and no significant relationship between the hand surface area and the 3-point shot percentage. The contemporary study results regarding the correlation between the hand anthropometric parameters of hand shape index, finger index and hand surface area and shot performance confirms the results of this study.

It was found that there was no statistically significant correlation between the hand grip strength, and the Aahperd shot test results in this study $(\mathrm{p}>0.05)$.

A similar study by Cicioğlu, Günay and Gökdemir (2000), examined and compared the hand grip strength of 111 elite female athletes from three different branches (41 basketball, 34 volleyball and 36 handball players). The average right hand grip strength was $27.28 \pm 5.24 \mathrm{~kg}$, and the mean left hand grip strength was $25.39 \pm 5.67 \mathrm{~kg}$ of elite female athletes in basketball, volleyball and handball branches. The right hand grip strength mean was $30.91 \pm 4.92 \mathrm{~kg}$, and the mean left hand grip strength value $27.31 \pm 3.73$ $\mathrm{kg}$ for handball players. Moreover, the mean right hand grip strength was $31.09 \pm 367 \mathrm{~kg}$ and the mean left hand grip strength was $30.48 \pm 3.60 \mathrm{~kg}$ for volleyball players. Gür, Kılınç, Ayhan, and Tunay (2017), showed that right and left hand grip strength affects the shot accuracy without specifying the dominant hand. Kinnunen, Colon, Mathilde, Overby, and Lewis (2001), conducted a study on 33 female basketball players aged between 8 and 11 without specifying the dominant hand and found a statistically significant correlation between free throw values and hand grip strength measurements $(\mathrm{p}<0.05)$. Hung, Chen, Lin, and Chung (2017), found that hand, palm and finger pressure significantly affect shooting accuracy. Gencer, Iğdır, Temur, Sarıkaya, and Seyhan (2019), conducted a study on 40 male- right-handed basketball players between the ages of 13-17 who play professional basketball in Van province. They stated that the non-dominant shot hand's grip strength does not affect the shooting accuracy the dominant shooting hand grip strength may increase shot accuracy and the success in the competitions. The results in relevant studies on the correlation between hand grip strength measurements and shooting performance show no consensus on this puzzling question. The reasons behind this are rooted in the age difference among the athletes, the examined league levels, the variety of training methods, and the anthropometric and conditional differences.

The correlation between the balance test and the Aahperd shot test results revealed that there was no statistically significant correlation between them $(p>0.05)$.

Çetinkaya (2019), conducted a study on 92 athletes, 48 females and 44 males, from 4 amateur basketball clubs competing in Çanakkale province. The flamingo balance test showed that the average for females in the star category was $4.00 \pm 2.45$, and the average in the junior category was $3.10 \pm 2.02$, while the Aahperd shot test was applied to determine the shot accuracy. The shooting test concluded that the average score of basketball players in the female stars category was $12.50 \pm 2.27$, while the average score in the youth category was $16.70 \pm 3.43$. The statistically compared results revealed that the more successful group in the balance test did not exhibit the same rates in shooting 
performance which shows that the balance performance did not contribute positively to the shooting performance. Tetik, Koç, Atar, and Koç (2013), compared the balance performance and game scores of the $1^{\text {st }}$ and $5^{\text {th }}$ teams that took part in an intercollegiate basketball tournament as it was stated that the balance and game score performance of the $1^{\text {st }}$ team was better than the $5^{\text {th }}$ team in the tournament. Considering these results on the correlation between balance test and shooting performance, the results are divergent from the results of this study. Thus, it can be asserted that similar studies reached different results while this study's results show similarities and differences in certain aspects.

\section{Conclusions}

The study reached contradictory results with its hypotheses, and the reason behind such a result may be that there are several factors effecting an accurate shot in basketball. Accurate shooting performance can be associated with anthropometric and conditioning factors and sociological and psychological status in particular. One factor affecting shooting accuracy is found to be the fans pressure, while other factors are specified as the athlete's self-confidence, comfort and responsibility to shoot. The minutes an athlete plays in a game, the league level, percentage of repetitive field goals made or missed shots are influential in the shooting dynamics. Another factor may be the anxiety about the future of the leagues, the suspensions of training and competitions due to the Covid19 process. In light of these findings, three parameters that could affect the shot performance examined in this study revealed that various hand anthropometric measurements, hand grip strength and balance ability were not significantly correlated with the shooting performance.

\section{Conflict of Interest Statement}

The authors declare no conflicts of interests.

\section{About the Authors}

Serdar Gür has a BS degree in physical education and a MA degree in Movement and Training Sciences. He works as a lecturer at Istanbul Gelisim University and his main branch is basketball. https://orcid.org/0000-0003-1562-9090; segur@gelisim.edu.tr Istanbul Gelişim University Vocational School İstanbul/Turkey.

Mehmet Soysal has a BS degree in physical education and a MA degree in Physical Education and Sports and a PhD in Physical Education and Sports Education. http://orcid.org/0000-0001-6528-0275; msoyal@gelisim.edu.tr; Coaching Department, School of Physical Education and Sport, Istanbul Gelisim University. 


\section{References}

Acar, N. (2016). Basketbolda esnekliğin motorik özelliklere etkisi. Yüksek Lisans Tezi, İstanbul Gelişim Üniversitesi, Sağlık Bilimleri Enstitüsü, İstanbul. [Effects of elasticity on motor properties in basketball. Master Thesis, Istanbul Gelişim University, Institute of Health Sciences, Istanbul]. (In Turkey).

Agarwal, P. and Sahu, S. (2010). Determination of hand and palm area as a ratio of body surface area in Indian population. Indian Journal of Plastic Surgery: Official Publication of the Association of Plastic Surgeons of India 43(1), 49.

Attila, A. (2019). Elit seviyedeki basketbolcuların bazı seçilmiş antropometrik özellikleri ile şut performansları arasındaki ilişkinin incelenmesi (Master's thesis, İstanbul Gelişim Üniversitesi Sağlık Bilimleri Enstitüsü). [Investigation of the relationship between some selected anthropometric features of elite basketball players and their shooting performance (Master's thesis, Istanbul Gelişim University Institute of Health Sciences)]. (In Turkey).

Barut, Ç., Demirel, P. ve Kıran, S. (2008). Evaluation of hand anthropometric measurements and grip strength in basketball volleyball and handball players. International Journal of Experimental and Clinical Anatomy, 2(1), 55-59.

Bassey, E. J. ve Harries, U. J. (1993). Normal values for handgrip strength in 920 men and women aged over 65 years, and longitudinal changes over 4 years in 620 survivors. Clin Sci, 84(3):331-337.

Büyüköztürk, Ş. (2007). Sosyal bilimler için veri analizi el kitabı. (7. Basım), Ankara: Pegem Akademi Yayınclık, s.40. [Manual of data analysis for social sciences. (7. Edition), Ankara: Pegem Academy Publishing, p.40]. (In Turkey).

Cicioğlu, İ., Gunay, M. ve Gökdemir, K. (1998). Farklı branşlardaki elit bayan sporcuların fiziksel ve fizyolojik profillerinin karşılaştırılması. Gazi Beden Eğitimi ve Spor Bil. Dergisi, III 4: 90. [Comparison of physical and physiological profiles of elite female athletes in different branches. Gazi Physical Education and Sports Know. Journal, III 4: 90]. (In Turkey).

Cortis, C.A., Tessitore, C., Lupo, C., Pesce, E., Fossile, F. and Capranica, L. (2011). Interlimb coordination, strength, jump, and sprint performances ollowing a youth men's basketball game. The Journal of Strength \& Conditioning Research, 25(1), $135-42$

Çetinkaya, C. (2019). Farklı altyapı kategorilerinde yer alan basketbolcuların bazı motorik özellikleri ile şut isabetlerinin yaş ve cinsiyete göre karşılaştırılması. Master's Thesis, İstanbul Gelişim Üniversitesi Sağllk Bilimleri Enstitüsü. [Comparison of some motoric features and shooting hits of basketball players in different infrastructure categories according to age and gender. Master's Thesis, Istanbul Gelişim University Institute of Health Sciences]. (In Turkey).

Demirel, P. (2005). El antropometrik ölçümleri ve el kavrama kuvvetinin farklı spor branşlarında karşılaştırılması. Master's thesis, Zonguldak Karaelmas Üniversitesi, Sağlık Bilimleri Enstitüsü, Anatomi Anabilim Dalı. [Hand anthropometric 
measurements and comparison of hand grip strength in different sports branches. Master's thesis, Zonguldak Karaelmas University, Institute of Health Sciences, Department of Anatomy]. (In Turkey).

Erculj, F and Supej, M. (2009). Impact of fatigue on the position of the release arm and shoulder girdle over a longer shooting distance for an elite basketball player. J Strength Cond Res 23: 1029-1036.

Gencer, Y. G., Iğdır, E. C., Temur, H. B., Sarıkaya, M. ve Seyhan, S. (2019). El kavrama kuvveti basketbolda şut isabetini etkiler mi? Electronic Turkish Studies, cilt. 14 say1 1, s. 371-380. 10p. [Does hand grip strength affect shooting accuracy in basketball? Electronic Turkish Studies, vol. 14 number 1, p. 371-380. 10p]. (In Turkey).

Gür, G., Kılınç, H. E., Ayhan, Ç. ve Tunay, V. B. (2017). Independent contributions of upper extremity variables in free throw shooting accuracy from multiple positions: A Pilot study in college basketball players. Spor Bilimleri Araştırmaları Dergisi, 2(1), 1-12. [Independent contributions of upper extremity variables in free throw shooting accuracy from multiple positions: A Pilot study in college basketball players. Journal of Sport Sciences Research, 2 (1), 1-12]. (In Turkey).

Hall, J. G., Froster-Iskenius, U. G. ve Allanson J. E. (1999). Handbook of normal physical measurements. Oxford University Press, Oxford, 1989, p. 221-224, 238-250.

Hung, C. F., Chen, C. C., Lin, S. H. ve Chung, T. K. (2017).Finger and palm dynamic pressure monitoring for basketball shooting. Journal of Sensors, 14-17.

Kamar. A. (2003). Sporda yetenek, beceri ve performans testleri. Nobel Yayın Dağıtım, Ankara, Aralık, s. 28-29. [Skill, skill and performance tests in sports. Nobel Yayin Dağıtım, Ankara, December, p. 28-29]. (In Turkey).

Karasar, N. (2011). Bilimsel araştırma yöntemleri. Ankara: Nobel Yayınları. [Scientific research methods. Ankara: Nobel Publications]. (In Turkey).

Kaushik, A., Sharma S. (2013). A Correlation Between Latency Period of Transverse Abdominis and Dynamic Balance: An EMG Study. Physiotherapy and Occupational Therapy Journal, 6(3)

Kinnunen, D. A., Colon, G., Espinoza, D., Overby, L. Y. ve Lewis D. K. (2001). Anthropometric correlates of basketball free-throw shootings by young girls. Perceptual and Motor Skills, 93, 105-108.

Kostopoulos N., Bekris E., Apostolidis N., Kavroulakis E., Kostopoulos P. (2012). The Effect Of A Balance And Proprioception Training Program On Amateur Basketball Players' Passing Skills. Journal of Physical Education and Sport, 12(3):316-323.

Krause, J. V, \& Nelson, C. (2018). Basketball skills \& drills. Human Kinetics.

Kulaksız, G. (2001). El dominansının, el antropometrik ölçümleri üzerine etkisinin incelenmesi. Gazi Üniversitesi, Tip Fakültesi Anatomi Anabilim Dalı, Uzmanlık Tezi, Ankara, s. 1-26. [Examination of the effect of hand dominance on hand anthropometric measurements. Gazi University, Faculty of Medicine, Department of Anatomy, Specialty Thesis, Ankara, p. 1-26]. (In Turkey). 
Lohman, T., Roche, A. ve Martorell, R. (1988). Anthropometric standardization manual. Human Kinetics, Champaign, IL.

Malone, L., Gervais, P. ve Steadward, R. (2002). Shooting mechanics related to player classification and free throw success in wheelchair basketball. Journal of Rehabilitation Research and Development, 39(6), 701-710.

Mülazımoğlu, O. (2012). The impact of fatigue on shooting in young basketball players. Selçuk University Journal of Physical Education and Sport Science, 14 (1), 37-41.

Napier, J. (1990). “Hands". Princeton University Pres, New Jersey, p. 24-27.

Okazaki, VHA, Okazaki, FHA, Sasaki, JE, and Keller, B. (2007). Speed accuracy relationship in basketball shoot. Fiep Bull 77: 745-747.

Pazarözyurt, İ. ve İnce, G. (2009). Elit bayan basketbolcularda antropometrik özellikler, dikey sıçrama ve omurga esnekliğinin mevkilere göre incelenmesi. Spormetre Beden Eğitimi ve Spor Bilimleri Dergisi, 6 (1), 9-18. [Anthropometric features, vertical jump and spinal flexibility in elite female basketball players according to positions. Spormeter Physical Education and Sport Sciences Journal, 6 (1), 9-18]. (In Turkey).

Pheasant, S. (1990). Anthropometrics: İntroduction. British Standard Institution, United Kingdom, p. 18-19.

Savas, S., Yüksel, M. F., \& Uzun, A. (2018). The Effects of Rapid Strength and Shooting Training Applied to Professional Basketball Players on the Shot Percentage Level. Universal Journal of Educational Research, 6(7), 1569-1574.

Şen, C., Durgun, C. ve Kozanoğlu, M. E. (2007). Deplasmanlı ligde basketbol oynayan sporcuların üst ekstremite morfolojik özelliklerinin mevkilere göre değerlendirilmesi. Spormetre Beden Eğitimi ve Spor Bilimleri Dergisi, (3), 135-138. [Evaluation of upper extremity morphological characteristics of athletes playing basketball in the away league according to their positions. Spormeter Journal of Physical Education and Sport Sciences, (3), 135-138]. (In Turkey).

Tamer, K. (2000). Sporda fiziksel-fizyolojik performansın ölçülmesi ve değerlendirilmesi. 2. Baskı, Bağırgan Yayımevi, Ankara, s. 32-42. [Measurement and evaluation of physical-physiological performance in sports. 2nd Edition, Bağırgan Publishing House, Ankara, p. 32-42]. (In Turkey).

Teramoto, M., Cross, C. L., Rieger, R. H., Maak, T. G. ve Willick, S. E. (2018). Predictive validity of national basketball association draft combine on future performance. The Journal of Strength \& Conditioning Research. 32(2), 396-408.

Tetik, S., Koç, M. C., Atar, Ö. ve Koç, H. (2013). Basketbolcularda statik denge performansı ile oyun değer skalası arasındaki ilişkinin incelenmesi. Türkiye Kickboks Federasyonu Spor Bilimleri Dergisi, 6(1), 9-18. [Investigation of the relationship between static balance performance and game value scale in basketball players. Turkey Kickboxing Federation of Sports Sciences Journal, 6 (1), 9-18]. (In Turkey). 
Visnapuu, M. and Jurimae, T. (2007). Handgrip strength and hand dimensions in young handball and basketball players. The Journal of Strength \& Conditioning Research, 21(3), 923-929.

Zemková, E. (2011). Assessment of balance assessment of balance in sport: science e in sport: Science in sport: science and reality. Serbian Journal of Sports Sciences. $5(4), 127-139$.

Ziv, G. ve Lidor, R. (2009). Physical Attributes, Physiological Characteristics, On- Court performance and nutritional strategies of female and male basketball players. Sports Medicine, 39(7), 547-568. 
Serdar Gür, Mehmet Soyal

EXAMINING THE EFFECTS OF HAND ANTHROPOMETRIC MEASUREMENTS, GRIP STRENGTH

AND BALANCE SKILLS ON SHOT PERFORMANCE IN ELITE FEMALE BASKETBALL PLAYERS

Creative Commons licensing terms

Authors will retain the copyright of their published articles agreeing that a Creative Commons Attribution 4.0 International License (CC BY 4.0) terms will be applied to their work. Under the terms of this license, no permission is required from the author(s) or publisher for members of the community to copy, distribute, transmit or adapt the article content, providing a proper, prominent and unambiguous attribution to the authors in a manner that makes clear that the materials are being reused under permission of a Creative Commons License. Views, opinions and conclusions expressed in this research article are views, opinions and conclusions of the author(s). Open Access Publishing Group and European Journal of Physical Education and Sport Science shall not be responsible or answerable for any loss, damage or liability caused in relation to/arising out of conflict of interests, copyright violations and inappropriate or inaccurate use of any kind content related or integrated on the research work. All the published works are meeting the Open Access Publishing requirements and can be freely accessed, shared, modified, distributed and used in educational, commercial and non-commercial purposes under a Creative Commons attribution 4.0 International License (CC BY 4.0). 